\title{
Varices periureterales
}

\author{
Ascaso Til H, Segarra Tomás J, Alberola J*, Villavicencio Mavrich H. \\ Servicio de Urología. *Radiología. Fundació Puigvert. Barcelona
}

Actas Urol Esp. 2008;32(4):471

\begin{abstract}
$\mathrm{M}$
ujer de 32 años, sin antecedentes médicos de interés, que acude a nuestro centro para estudio de hematuria macroscópica monosintomática. Se realizan ecografía y cistoscopia que resultan normales, así como estudio de dismorfia eritrocitaria (> $80 \%$ isomórficos). En la urografía intravenosa (Fig. 1) se observa que el uréter izquierdo presenta improntas en su tercio medio y superior que le confieren un aspecto arrosariado y que son compatibles con varicosidades periureterales.

Durante el tiempo de seguimiento no se repitió el cuadro de hematuria macroscópica, y las cifras de hemoglobina y creatinina se mantuvieron dentro de la normalidad, por lo que no se ofreció ningún tratamiento.
\end{abstract}

Correspondencia autor: Dra. H. Ascaso Til

Servicio de Urología. Fundació Puigvert.

Cartagena 340-350, 08025 Barcelona. Tel.: 934169700

E-mail autor: hascasotil@yahoo.es

Información artículo: Imágenes en Urología

Trabajo recibido: noviembre 2006

Trabajo aceptado: diciembre 2007

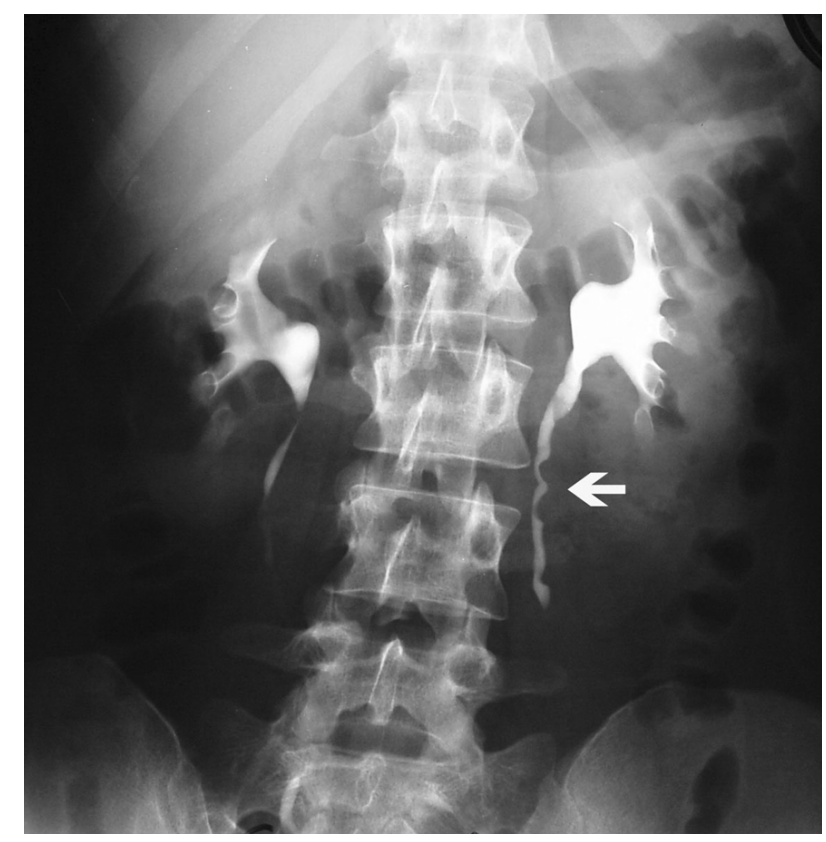

FIGURA 1. Uréter izquierdo de aspecto arrosariado en tercio medio y superior que sugiere impronta extrinseca, compatible con varicosidades periureterales. 